\title{
A personagem em José Saramago: dialética e humanismo
}

\author{
The character in José Saramago: dialectic and humanism
}

\author{
DEIVIS JHONES GARLET ${ }^{1}$ \\ ROSANI KETZER UMBACH ${ }^{1}$ \\ ${ }^{1}$ Universidade Federal de Santa Maria. Porto Alegre, RS, Brasil.
}

\begin{abstract}
Resumo: Ao reconhecer a dialética e o humanismo como princípios de construção estética em José Saramago, propomos um estudo da categoria narrativa da personagem na obra do autor, com o objetivo de explicitar seu funcionamento e seu acabamento axiológico. Partiremos do paradigma de que a explicação do literário - aqui em relação à personagem - necessita partir do interior do universo ficcional, isto é, a função que exerce na estrutura da obra. Com esse paradigma de investigação, advogaremos em defesa do funcionamento dialético da personagem; da sua constituição dialógica, intimamente relacionada a sua dialeticidade; e da articulação da vida da personagem quanto ao eixo semântico humanista-democrático, todos esses três elementos inter-relacionados de modo a construir uma certa cosmovisão de vida, de Homem. Para tornar o argumento mais sólido, recorreremos a alguns pressupostos de análise da personagem já tradicionais, como as propostas de Hamon, de Forster e de Bakhtin.
\end{abstract}

Palavras-chave: Personagem; Dialética; Humanismo.

\begin{abstract}
In recognizing the dialectic and humanism as principles of aesthetic construction of José Saramago, we propose a study of the narrative category of the character in the author's work, with the purpose of explaining its functioning and its axiological finishing. We will start from the paradigm that the explanation of the literary - here in relation to the character - needs to start from the interior of the fictional universe, that is, the function that it exerts in the structure of the work. With this paradigm of investigation, we will advocate in defense of the dialectical functioning of the character; of its dialogical constitution, closely related to its dialectic; And of the articulation of the life of the person in relation to the humanist-democratic semantic axis, all three interrelated elements in order to construct a certain worldview of life, of Man. To make the argument more solid, we will resort to some of the traditional assumptions of character analysis, such as the proposals of Hamon, Forster and Bakhtin.
\end{abstract}

Keywords: Character; Dialectic; Humanism.

A obra saramaguiana apresenta, com frequência recorrente, um conteúdo humanista e humanitário, segundo Arnaut (2006). Um humanismo que se evidencia na recuperação de valores como a solidariedade, a generosidade, a fraternidade, o bem-comum, em uma palavra, o amor. No entanto, não se trata de uma tabela de valores imposta à revelia do homem situado historicamente, em um evento singular e irrepetível, com o consequente dogmatismo de um império dos valores. Muito pelo contrário, o humanismo saramaguiano recusa as concepções de ética normativa, concedendo a primazia ao homem em relação aos valores e princípios universais. Assim, o sujeito é responsável absoluto por sua existência - seus atos - para si e para os outros, de modo bastante próximo ao humanismo de Bakhtin (2010b) e de Sartre (2014). No universo romanesco do autor luso, a posição humanista constrói-se no e pelo conflito entre diferentes posições axiológicas nos eventos ímpares da existência.

Reconhecido o humanismo presente no conteúdo das narrativas de José Saramago, argumentaremos que sua exitosa realização ocorre por meio de uma forma dialética, a qual assume a qualidade de princípio artístico, apreensível pela análise das categorias narrativas, aqui delimitando-nos à personagem. Na dialética, de acordo com Lefebvre (1975), o movimento das contradições é contínuo. A contradição já se constitui como negação da negação, superando-se pela proposição da elevação de nível, ou seja, a síntese - a qual, por sua vez, já engloba 
novas contradições em perpetuum mobile. É importante salientar que a dialética não comporta uma simples oposição de elementos, ou mesmo sua aglutinação. As contradições dialéticas possuem caráter interno, apresentam um movimento essencial e não imposto do exterior. Ao mesmo tempo, engendram algo novo, uma síntese. Ora, para que tal esquema se processe é necessário que as contradições encerrem dois termos contraditórios no âmago de uma unidade, pois do contrário recai-se em uma dicotomia, na qual os dois termos são, necessariamente, excludentes. A dialética, portanto, ao ensejar o movimento - por meio das tensões - constitui-se como princípio estético que realiza o conteúdo humanista e, adicionaremos, também democrático, uma vez que - tanto no princípio artístico, quanto no conteúdo axiológico - o dissenso e o respeito ao outro constituem pedra angular.

Neste estudo, no qual concederemos prioridade à personagem, o anterior introito se justifica pelo fato de que as personagens percorrem um caminho dialético, no qual suas ações entram em contradição profunda e crítica, sendo também pelas suas ações, como sujeitos ativos no decorrer dos fatos, que interferem na realidade ficcional. Não são personagens única e simplesmente opostas, mas dialeticamente contraditórias e relativamente autônomas, e, como advogaremos, representativas de uma cosmovisão. $\mathrm{Na}$ análise que propomos, tomaremos por corpus os romances Ensaio sobre a cegueira (1995), Ensaio sobre a lucidez (2004) e As intermitências da morte (2005), conjecturando, porém, a extensão de nossas conclusões para o restante da obra romanesca do autor.

Ao tomar por premissa a asserção de Candido (2011, p. 77) de que a "chave mestra da eficácia dum romance, a condição do seu pleno funcionamento, e portanto do funcionamento das personagens, depende dum critério estético de organização interna", queremos recusar um trabalho analítico que concede a primazia aos possíveis modelos exteriores - do mundo real concreto - que possam ter influído na confecção da personagem, ressaltando, porém, a relevância de tal hipótese de trabalho com finalidades ad hoc. Em José Saramago, mais do que buscar expor possíveis influências de pessoas da vida cotidiana do autor, ou de personalidades históricas, parece-nos mais relevante e apropriado laborar no sentido de reconhecer e compreender a "função que [a personagem] exerce na estrutura do romance" (CANDIDO, 2011, p. 75). Com esse paradigma de investigação, advogaremos em defesa do funcionamento dialético da personagem; da sua constituição dialógica, intimamente relacionada a sua dialeticidade; e da articulação da vida da personagem quanto ao eixo semântico humanista-democrático, todos esses três elementos inter-relacionados de modo a construir uma certa cosmovisão de vida, um modelo ideal de homem - de humanidade - sem, no entanto, romantizar a pessoa ficcional, antes, pelo contrário, expô-la como o homem comum, mediano, na acepção de Lukács (2010). Para tornar o argumento mais sólido, recorreremos a alguns pressupostos de análise da personagem já tradicionais, como as propostas de Hamon (1976) e de Forster (1969).

De acordo com Hamon (1976), o estudo da personagem - e do romance - deve evitar impor códigos exteriores ao universo ficcional, pois assim procedendo será lícito apresentar discordantes visões sobre uma mesma personagem em conformidade com os valores de diferentes épocas, recaindo-se em um relativismo estéril. Para o teórico francês, a essência da personagem deve ser buscada no código original próprio a cada obra literária, oriundo de valores específicos. Assim, Hamon constrói uma metodologia para o estudo da personagem da qual ressaltamos: a identificação do herói a partir de suas relações diferenciais com as outras personagens e ações e a percepção dos eixos semânticos pertinentes a cada relação. Partindo dessa orientação, não nos é difícil precisar as protagonistas dos romances aqui em estudo: a mulher do médico, em Ensaio sobre a cegueira, o comissário de polícia, em Ensaio sobre a lucidez, e a morte, em As intermitências da morte. Todas as três apresentam alto grau de diferenciação para com o sistema de personagens, sobretudo em torno do eixo-semântico humanista-democrático, mas também por receberem um acento emotivo-volitivo mais intenso, seguindo-se, aqui, proposição de Tomachevski (2013, p. 342) para a identificação do herói, ou seja, aquele que "recebe o matiz emocional mais vivo e mais acentuado".

De fato, é possível percebermos uma distribuição e uma qualificação diferencial nas três personagens antes citadas, definidas na relação com a alteridade e com o eixo semântico. Tomemos o caso idiossincrático de cada personagem em separado.

A mulher do médico, no Ensaio sobre a cegueira, notoriamente possui a distribuição diferencial. Ela está presente e é decisiva na maior parte dos episódios de alto teor dramático, os momentos de crise e superação dialética. Sua presença em tais momentos é imprescindível, o mesmo não se verificando com outras personagens. Assim, por exemplo, na cena em que assassina o líder dos cegos "malvados", houvera um amplo precedente de recrudescente tensão - desde a própria situação deplorável dos cegos no manicômio até a exigência de pagamento pela comida e a cena do estupro coletivo - configurador de um movimento contínuo, interrompido, bruscamente, pela mudança qualitativa, ou seja, o assassinato dos "malvados". A decisão e a ação de matar somente poderia ser dela, primeiramente porque detentora da faculdade de ver, enquanto todas as demais personagens encontravam-se 
limitadas pela cegueira; em segundo lugar, porque proprietária de uma tesoura, a qual serviria de arma letal. Com efeito, a mulher do médico possui uma frequência que ultrapassa todas as demais personagens, e é necessária em cada situação determinada da narrativa. Corrobora o seu protagonismo o fato de ela, mais do que qualquer outra personagem, apresentar momentos de desvelamento de sua consciência interior, como pode-se observar nas seis ocasiões em que vê a tesoura antes de decidir matar, ampliando seu caráter diferencial.

De modo semelhante, em Ensaio sobre a lucidez, o comissário de polícia incorpora o matiz emotivo-volitivo mais acentuado. A partir do momento em que aparece na narrativa, enviado pelo governo à capital para averiguar a culpa da mulher do médico na maciça votação em branco, sua presença e ação tornam-se absolutamente necessárias. É ele que se transforma dialeticamente, a partir do contato com a cidade sitiada e com a mulher do médico, para, em um salto qualitativo, superar o seu estado inicial, ou seja, a cumplicidade quanto aos planos nefastos do governo. $\mathrm{O}$ mesmo não ocorre, por exemplo, com seus dois ajudantes, cuja presença é contingente e não recebem um tratamento da consciência interior. Exemplar nesse sentido é a cena em que - após o diálogo com a mulher do médico - o comissário se apercebe do absurdo da situação em que se encontrava:

Até este momento o comissário havia tido muito claro na sua cabeça o objectivo da missão de que fora encarregado pelo ministro do interior, nada mais que averiguar se haveria alguma relação entre o fenómeno do voto em branco e a mulher que tinha na sua frente, mas a interpelação dela, seca e directa, deixara-o desarmado, e, pior do que isso, com a súbita consciência do tremendo ridículo em que cairia se lhe perguntasse, de olhos baixos porque não teria coragem para a olhar cara a cara, Por acaso não será a senhora a organizadora, a responsável, a chefa do movimento subversivo que veio pôr o sistema democrático numa situação de perigo a que talvez não seja exagerado chamar mortal, Qual movimento subversivo, quereria ela saber, $\mathrm{O}$ do voto em branco, Está a dizer-me que o voto em branco é subversivo, tornaria ela a perguntar, Se for em quantidades excessivas, sim senhor, $E$ onde é que está escrito, na constituição, na lei eleitoral, nos dez mandamentos, no regulamento de trânsito, nos frascos de xarope, insistiria ela, Escrito, escrito, não está, mas qualquer pessoa tem de perceber que se trata de uma simples questão de hierarquia de valores e de senso comum, primeiro estão os votos explícitos, depois vêm os brancos, depois os nulos, finalmente as abstenções, está-se mesmo a ver que a democracia ficará em perigo se uma destas categorias secundárias passar à frente da principal, se os votos estão aí é para que façamos deles um uso prudente, E eu sou a culpada do sucedido,
É o que estou tratando de averiguar, E como foi que que consegui levar a maioria da população da capital a votar em branco, metendo panfletos debaixo das portas, por meio de rezas e esconjuros à meia noite, lançando um produto químico no abastecimento de água, prometendo o primeiro prêmio da lotaria a cada pessoa, ou gastando a comprar votos o que o meu marido ganha no consultório, A senhora conservou a visão quando toda a gente estava cega e ainda não foi capaz ou recusa-se a explicar-me o porquê, $E$ isso torna-me agora culpada de conspiração contra a democracia mundial, É o que trato de averiguar, Pois então averigúe e quando tiver chegado ao fim da investigação venha cá dizer-me, até lá não ouvirá da minha boca nem mais uma palavra (SARAMAGO, 2004, p. 232-233, grifos nossos).

O diálogo é imaginado e ocorre na consciência do comissário, no período que decorre entre a indagação direta da mulher do médico de qual era o assunto e quem mandara-o a morada e a retomada da cena, com o toque da campainha e a chegada do inspetor. Nos grifos em negrito, temos as possíveis justificativas que daria para o seu ato investigativo, já com uma entonação pouco convincente, sobretudo pela expressão "mortal", uma hipérbole que sugere o irracional absurdo da situação; nos grifos em itálico, as possíveis réplicas da mulher do médico, de maneira a realçar a falta de conexão entre crime e voto em branco, voto em branco e culpa, não cegar e ser a líder dos "brancosos"; nos grifos em sublinhado, a insensatez da acusação é salientada pelas expressões que remetem a uma total impossibilidade racional de ela ter relação com o caso do voto em branco. Com certeza, há um tom kafkiano na situação, viabilizando, todavia, a tomada de consciência do comissário quanto ao absurdo e pérfido plano do governo. Com isso, ocorre a superação dialética: o comissário - ainda pertencente ao governo - passa a agir em defesa da mulher do médico. Nenhuma outra personagem nos é apresentada de maneira tão enfática, em momentos de superação dialética e com sua consciência interior, configurando uma frequência e uma qualificação diferencial.

Em As intermitências da morte, a morte assume o protagonismo. Desde o momento em que anuncia seu retorno, por meio de uma carta, a morte - enquanto personagem - torna-se o epicentro das atenções do narrador. Igualmente aos exemplos anteriores, sua frequência nas situações decisivas é constante, sendo difícil conceber a sobrevida da narrativa sem ela. A morte, em um processo contínuo, vai sendo colorida com tonalidades humanas, sem, no entanto, deixar sua condição essencial de morte. Ela sente fadiga, suspira, zanga-se, emociona-se, fascina-se pelo desenho de uma borboleta até, com uma mudança qualitativa, tornar-se humana e relacionar-se com o músico. Antes de tal superação dialética, no entanto, há 
um contínuo movimento de tensões, as quais viabilizam o desvelamento subjetivo da personagem morte, até mesmo por meio da exposição de sua consciência interior, fato que a distingue das demais personagens e a qualifica como a protagonista do relato. A morte, diferentemente das personagens dos Ensaios, é contemplada com uma descrição da sala onde mora, dos seus arquivos, da sua figura física, contribuintes para o estabelecimento de seu protagonismo.

É, portanto, no processo relacional que as personagens se definem e se autorrevelam, de forma dialógicadialética, na medida em que representam um "ponto de vista especifico sobre o mundo e sobre si mesma, como posição racional e valorativa do homem em relação a si mesmo e à realidade circundante" (BAKHTIN, 2010a, p. 52, grifo do autor), recusando a interferência monológica de uma instância narrativa. Nesse sentido, a qualificação diferencial das protagonistas, embora possa ser atribuída a outros fatores de menor impacto, dá-se pelo relacionamento tenso com a alteridade, sobremodo em relação ao eixo semântico do humanismodemocrático. A mulher do médico, no Ensaio sobre a cegueira, configura um ideal de conduta humanista e democrática, sendo compreensiva, solidária, preocupada com o bem-estar comum, aberta ao diálogo, em síntese, amorosa. Não há uma descrição de sua personalidade, mas percebemos esse modelo de conduta pelos seus pensamentos, pelas suas ideias expressas em diálogos, pela voz de outras personagens e do próprio narrador e, sobretudo, pelas suas ações. Ela, sem se impor, surge naturalmente como a líder do seu grupo, reconhecida e apoiada pela maioria - veja-se o caso em que o velho da venda preta a impede de revelar o assassínio do líder dos cegos "malvados", ante as queixas dos cegos famintos, "Mataria com as minhas mãos quem a si próprio se denunciasse, Porquê, perguntaram da roda, Porque se a vergonha ainda tem algum significado neste inferno do inferno [...] é graças a essa pessoa que teve a coragem de ir matar a hiena ao covil da hiena" (SARAMAGO, 1995, p. 191); ou ainda a decisão da mulher que ela havia salvo do estupro coletivo, ao afirmar "Aonde tu fores eu irei" (SARAMAGO, 1995, p. 192), - revelando-se, via alteridade, a personalidade da protagonista. Enfim, a mulher do médico, como a protagonista do romance, simboliza um ideal de humanidade, ideal calcado no humanismo-democrático saramaguiano, mormente em relação a uma posição axiológica em prol da racionalidade, da responsabilidade, da solidariedade, da compaixão, do amor e de um comportamento dialógico e democrático. Não é difícil encontrar aqui certas ressonâncias do modelo da personagemCristo de Dostoiévski, como pode-se notar na seguinte cena:
Quando o médico e o velho da venda preta entraram na camarata com a comida, não viram, não podiam ver, sete mulheres nuas, a cega das insónias estendida na cama, limpa como nunca estivera em toda a sua vida, enquanto outra mulher lavava, uma por uma, as suas companheiras, e depois a si própria (SARAMAGO, 1995, p. 181).

A cena, contextualizada no todo de ações da mulher do médico, estabelece uma relação em nada incidental com o texto bíblico ${ }^{1}$, sobremodo a homologia simbólica com o ato de Jesus de lavar os pés dos apóstolos, como um exemplo de humildade do mestre para ser seguido pelos discípulos. A mulher do médico, considerando o todo de suas ações, encarna, portanto, uma idealização de conduta, assemelhada ao humanismo de Cristo, cujo núcleo é o amor. Como afirmamos anteriormente, ela vai se construindo gradativamente, pela tensão com a alteridade e, com isso, angariando empatia do leitor. Assim, considerando o eixo semântico humanista-democrático, perceberemos que nenhuma outra personagem o encarna de modo tão significativo, muito embora diversas apresentem o modelo de forma episódica. Outras simbolizam a antítese, a exemplo do líder dos cegos "malvados", do governo, dos soldados, dos cegos da cidade, ou seja, é pelo choque com a carência de humanismo e de valores democráticos destes que se constitui o modelo humanista e democrático da mulher do médico.

Similar é o caso do comissário de polícia, em Ensaio sobre a lucidez, não obstante ele não possuir a intensidade da carga simbólica que a mulher do médico apresenta. O comissário salienta-se, sobretudo, pela mudança dialética que efetua ao desabonar os planos do governo. A partir de então, ele se choca com toda a representatividade autoritária, violenta e imoral dos governantes, especialmente quanto ao primeiro-ministro e o ministro do interior, revelando-se como uma antítese à elite política. Podemos afirmar que a constituição subjetiva das personagens se erige a partir do eixo semântico humanista-democrático, insuficiente no governo e frequente na maioria das demais personagens. Pode-se explicitar o exposto com a Tabela 1, ressaltando-se que citamos apenas aquelas personagens que nos parecem mais significativas para o universo ficcional e, também, que não se deseja, com a ilustração, sugerir

\footnotetext{
De acordo com evangelho de João, capítulo 13, versículos 5 ao 13: "Em seguida pôs água numa bacia e começou a lavar os pés dos discípulos e a enxugá-los com a toalha. Quando chegou perto de Simão Pedro, este lhe perguntou: - Vai lavar os meus pés, Senhor? Jesus respondeu: - Agora você não entende o que estou fazendo, porém mais tarde vai entender! [...] Depois de lavar os pés dos seus discípulos, Jesus vestiu de novo a capa, sentou-se outra vez à mesa, e perguntou: - Vocês entenderam o que eu fiz? Vocês me chamam de Mestre e de Senhor e têm razão, pois eu sou mesmo. Se eu, o Senhor e Mestre, lavei os pés de vocês, então vocês devem lavar os pés uns dos outros. Pois eu dei o exemplo para que vocês façam o que eu fiz" (BÍBLIA SAGRADA, 2005, p. 1246).
} 
uma estaticidade das personagens, ou mesmo a dicotomia insuperável. O que se ressalta é uma tendência dominante, considerando-se os atos, os pensamentos e as falas das mesmas durante a narrativa.

Tabela 1. Disposição das personagens em relação ao eixo semântico humanista-democrático (intensidade alta, média ou baixa)

\begin{tabular}{lcc}
\hline \multirow{2}{*}{ Personagem } & \multicolumn{2}{c}{ Eixo semântico } \\
\cline { 2 - 3 } Presidente & Média & Média \\
\hline Primeiro-ministro & Baixa & Baixa \\
Ministro do Interior & Baixa & Baixa \\
Ministro da Defesa & Baixa & Baixa \\
Ministro da Cultura & Média & Média \\
Ministro da Justiça & Média & Média \\
Presidente da Câmara Municipal & Média & Média \\
Comissário de polícia & Alta & Alta \\
Mulher do médico & Alta & Alta \\
"Brancosos" & Alta & Alta \\
\hline
\end{tabular}

As personagens ligadas ao governo acabam por se dividir, em relação a uma predominância: quatro apresentam comportamento humanista e democrático, outras quatro, apresentam comportamento autoritário e violento, como antítese ao primeiro grupo. Elas não são estáticas, pois evoluem: do autoritarismo violento para o humanismo e a democracia, a exemplo, bastante significativo, dos ministros da justiça e da cultura, além do presidente da câmara e do comissário de polícia. No interior de um núcleo de autoritarismo, ao qual podemos atrelar o presidente, o primeiro-ministro e os ministros da defesa e do interior, também ocorrem mudanças, no caso, para a exacerbação do comportamento violento e ditatorial. É possível identificar também dois grandes grupos, os quais simbolizam o contraponto entre o autoritarismo e a democracia, a violência e o humanismo, localizados, respectivamente, no governo e nos "brancosos". O comissário de polícia, de forma dialógica-dialética transita do primeiro para o segundo grupo, sem, todavia, deixar de pertencer ao aparato governamental, fato que não ocorre com os ministros da justiça e da cultura e o presidente da câmara, pois, ao efetuarem a superação dialética de seu estado inicial, excluem-se da governança. Parece-nos, portanto, bastante acertado que - de fato há uma qualificação diferencial do comissário de polícia, segundo o eixo-semântico estruturador da obra.

Em As intermitências da morte, a protagonista também se constrói no processo relacional. A sua qualificação, segundo o eixo político-ideológico geral da obra, edifica-se pelo confronto que seus pensamentos e ações estabelecem para com os diversos setores públicos e privados atingidos pela suspensão e regresso da morte, sobressaindo - neste romance - muito mais o humanismo do que a democracia, ainda que a conduta contrária aos valores de humanismo possa ser correlacionada a um comportamento antidemocrático. Observe-se a Tabela 2, na qual as instituições (públicas ou privadas) foram tomadas como representativas de personagens.

Tabela 2. Disposição das personagens em relação ao eixo semântico humanista-democrático (intensidade alta, média ou baixa)

\begin{tabular}{lcc}
\hline \multirow{2}{*}{ Personagem } & \multicolumn{2}{c}{ Eixo semântico } \\
\cline { 2 - 3 } Morte & Humanismo & Democracia \\
Violoncelista & Média & Média \\
Governo & Baixa & Baixa \\
Funerárias & Baixa & Baixa \\
Asilos & Baixa & Baixa \\
Hospitais & Baixa & Baixa \\
Seguradoras & Baixa & Baixa \\
Máphia & Baixa & Baixa \\
\hline
\end{tabular}

Como se pode perceber, há um grande grupo que pode ser caracterizado em oposição ao eixo semântico geral, caso do governo, das funerárias, dos asilos, dos hospitais, das seguradoras e da máphia. Para estes, a suspensão e o regresso da morte são vistos apenas de acordo com interesses econômicos, camuflados, todavia, por supostas preocupações humanitárias. Ao desumano tratamento destes setores para com a população corresponde um comportamento progressivamente humanista da morte. Esta, ao retornar à ativa, avisa sobre os futuros óbitos por meio de missivas, concedendo, inclusive, tempo para que as pessoas ajustem suas vidas antes de morrer. Quando do retorno da carta cujo destinatário era o violoncelista, a morte fica desconcertada e, em uma paulatina humanização, toma a figura de uma mulher e apaixona-se pelo músico: a morte, humanizada, ama, sem, todavia, deixar sua essência de morte - em uma transformação dialógica-dialética. $\mathrm{O}$ humanismo que parece sobressair neste romance diz respeito ao amor, afinal a morte opera sua mudança qualitativa devido a ele, e, com isso, há um retorno antitético aos demais personagens para ratificar suas condutas pouco amorosas para com a humanidade.

Com o exposto até o momento, podemos concluir que as personagens saramaguianas constituem consciências relativamente independentes, revelando-se no e pelo contato com o outro, com outras consciências, o que lhes assegura um acabamento dialógico segundo a tese bakhtiniana de que a autoconsciência da personagem 
"em todos os seus momentos está voltada para fora, dirige-se intensamente a si, a um outro, a um terceiro" (BAKHTIN, 2010a, p. 292). Efetivamente, as personagens de José Saramago possuem consciências relativamente autônomas, construindo-se de forma dialógica-dialética, como pode-se observar no confronto entre a consciência da mulher do médico e a simbólica consciência dos cegos "malvados", do governo, dos soldados, entre outros; no conflito entre o comissário de polícia e o governo; na tensão entre a autoconsciência da morte e a das funerárias, asilos, hospitais, entre outros. Uma tensão de contraditórios no interior de uma totalidade semântica sintetizada por nós no humanismo-democrático. Assim, se as personagens são dialógicas e transformam-se dialeticamente, parece-nos bastante razoável atribuirlhes a denominação de redondas, segundo classificação de Forster (1969). A personagem redonda, conforme exposto pelo autor, caracteriza-se pela dinâmica e pela consciência, sendo também a ela concedido o espaço para reflexões autônomas em relação a si, ao outro e ao mundo. Em suma, de acordo com Forster (1969, p. 61), "O teste para uma personagem redonda está nela ser capaz de surpreender de modo convincente. Se ela nunca surpreende, é plana. Se não convence, é plana pretendendo ser redonda".

Considerando-se a assertiva de Forster, podemos identificar diversos momentos em que as personagens saramaguianas surpreendem, impedindo uma síntese de sua vivência em uma frase sentenciosa. Quanto à mulher do médico, o episódio de maior surpresa, sem dúvida, ocorre quando comete o assassínio do líder dos cegos "malvados". Tomando-se a ação de matar isoladamente, há uma discrepância para com o ideal humanitário que ela representa. Porém, ao considerar o todo romanesco-desde as extremas dificuldades de sobrevivência no manicômio até a violação sexual das mulheres - perceberemos que, naquela situação singular e irrepetível, o ato de matar constituiu uma ação em defesa da dignidade humana, da vida. Dessa forma, uma definição do humanismodemocrático saramaguiano em termos universalistas não se sustenta, pois é na experiência individual e específica da vivência concreta que ele deve ser apreendido. A mulher do médico surpreende por matar, mas, a partir de um rigoroso exame das circunstâncias em que o faz, opera-se uma inversão de significado para o seu ato. Apesar disso, ela apresenta intenso conflito interior, antes e depois do fato, sendo que sua atitude é alvo de apreciação sob os mais diferentes pontos de vista: há uma voz coletiva que condena sua atitude, sobremaneira pelo fato de estarem famintos, "O que devíamos fazer era tomar a justiça nas nossas mãos e levá-lo ao castigo, Desde que soubéssemos quem é" (SARAMAGO, 1995, p. 191); a voz conciliadora do esposo, ao afirmar que "Ainda há quem esteja aqui a pensar em descobrir quem matou aquele, ou estaremos de acordo em que a mão que o foi degolar era a mão de todos nós, mais exactamente a mão de cada um de nós" (SARAMAGO, 1995, p. 193); além de um diálogo repleto de tensão entre as diferentes vozes:

\begin{abstract}
eu, por exemplo, matei um homem, Mataste um homem, espantou-se o primeiro cego, Sim, o que mandava do outro lado, espetei-lhe uma tesoura na garganta, Mataste para vingar-nos, para vingar as mulheres tinha de ser uma mulher, disse a rapariga dos óculos escuros, e a vingança, sendo justa, é coisa humana, se a vítima não tiver um direito sobre o carrasco, então não haverá justiça, Nem humanidade, acrescentou a mulher do primeiro cego (SARAMAGO, 1995, p. 245, grifos nossos).
\end{abstract}

Nota-se o tom reprovativo na voz do primeiro cego, grifo em sublinhado, especialmente pela entonação expressa pelo narrador ao afirmar que ele havia se "espantado", possivelmente por considerar - segundo um padrão de valores que se pretende universal - o ato de matar censurável em qualquer contexto. Choca-se com esse entendimento a opinião da rapariga dos óculos escuros e da mulher do primeiro cego, grifo em negrito, que salienta o humanismo do ato perpetrado pela mulher do médico. A voz desta, grifo em itálico, embora pareça muito insensível, oculta os tormentos que ela experimenta antes e depois de cometer o assassinato. Precede a tomada de ação um longo conflito interior, no qual ela observa a tesoura seis vezes, com o intuito de usá-la, mas sempre - por um mecanismo psíquico de negação - desvia o pensamento. Após matar o líder dos cegos "malvados" e depois de ameaçar com rigidez o cego contabilista, que havia assumido a posse da arma de fogo, toda sua qualidade de homem comum se demonstra, pois:

deu uns quantos passos ainda firmes, depois avançou ao longo da parede do corredor, quase a desmaiar, de repente os joelhos dobraram-se, e caiu redonda. Os olhos nublaram-se-lhe, Vou cegar, pensou, mas logo compreendeu que ainda não ia ser desta vez, eram só lágrimas o que lhe cobria a visão, lágrimas como nunca as tinha chorado em toda a sua vida, Matei, disse em voz baixa, quis matar e matei [...] Velha e assassina, pensou, mas sabia que se fosse necessário tornaria a matar, E quando é que é necessário matar, perguntou-se a si mesma enquanto ia andando na direç̧ão do átrio, e a si mesma respondeu, Quando já está morto o que ainda é vivo (SARAMAGO, 1995, p. 188-189).

A mulher do médico é, portanto, profundamente humana, na medida em que é forte para suportar o peso de auxiliar o grupo, mas igualmente abalável pelas contínuas provações a que é submetida; é convicta do 
que é necessário executar, como o assassinato, mas hesita e sofre antes e depois de fazê-lo; apresenta, pois, uma caraterização de um prosaico humanismo.

O comissário de polícia, em Ensaio sobre a lucidez, por seu turno, surpreende - de maneira mais emblemática - ao decidir pela inocência da mulher do médico, contrariando expressamente as ordens do governo, na figura do ministro do interior. O comissário, em um processo dialógico-dialético, entra em contato com a realidade da cidade sitiada, com os acusados, e apercebese do absurdo da acusação que pesava sobre a mulher do médico, operando-se uma mudança qualitativa em seu ser: de assecla do governo, pela contradição interposta pela cidade e pelos acusados, supera o papel inicial para passar a agir em defesa da justiça, ou seja, da defesa da inocência da mulher do médico diante das ilógicas acusações governamentais. O comissário também nos é colorido como um homem comum, em seus erros e acertos, em sua força e em sua fraqueza, restando, ao fim, assassinado pelo agente enviado pelo aparato governamental. A essência humanista da personagem nos é revelada pelas suas ações e pelos seus pensamentos, por vezes pelo diálogo direto, como vemos na seguinte cena, na qual o comissário conversa com o ministro do interior, este alcunhado albatroz, aquele papagaio-do-mar, em uma comunicação cifrada estabelecida pelo ministro do interior, em estilo policialesco:

Posso fazer uma pergunta, albatroz, Faça-a que eu responderei, papagaio-do-mar, sempre fui bom em dar respostas, Que acontecerá se não se encontrarem provas da culpabilidade, $\mathrm{O}$ mesmo que aconteceria se não se encontrassem provas da inocência, Como devo entendê-lo, albatroz, Que há casos em que a sentença já está escrita antes do crime, Sendo assim, se entendi bem aonde quer chegar, rogo-lhe que me retire da missão, albatroz (SARAMAGO, 2004, p. 244).

O diálogo, como podemos observar, expõe antiteticamente as opiniões das personagens envolvidas, a respeito da culpa ou da inocência da mulher do médico. Pela via do confronto, desnuda-se a hipocrisia do ministro do interior, seu plano de culpar uma inocente, e, paralelamente, o comportamento humanista-democrático do comissário, ao decidir não pactuar como o pérfido plano. Na sequência da narrativa, em outro diálogo envolvendo as duas personagens, a tensão de contrários exacerba-se, perfazendo a superação dialética, o salto qualitativo do comissário:

Então vá directamente ao assunto e responda-me se pode afirmar que a mulher do médico tem responsabilidade no movimento organizado para o voto em branco, que talvez mesmo seja ela a cabeça de toda a organização, Não, albatroz, não o posso afirmar, Porquê, papagaio-do-mar, Porque nenhuma polícia do mundo, e eu considero-me o último de todo eles, albatroz, encontraria o menor indício que the permitisse fundamentar uma acusação dessa natureza, Parece ter-se esquecido de que havíamos acordado em que plantaria as provas necessárias, papagaio-do-mar [... A partir deste momento dou por terminada a comédia dos nomes em cifra, você é um comissário da polícia e eu sou ministro do interior, Sim senhor ministro, Para ver se nos entendemos de uma vez, vou formular de maneira diferente a pergunta que há pouco lhe fiz, Sim senhor ministro, Está disposto, à margem das suas convicções pessoais, a afirmar que a mulher do médico é culpada, responda sim ou não, Não senhor ministro, Mediu as consequências do que acaba de dizer, Sim senhor ministro (SARAMAGO, 2004, p. 273, grifos nossos).

As expressões grifadas em sublinhado revelam o desonesto plano do governo de culpar, a qualquer preço, a mulher do médico - explicitamente sugerindo a invenção de provas, se necessário. Além disso, contém uma entonação ameaçadora, com a inevitável imposição de uma autoridade autoritária sobre um interlocutor hierarquicamente inferior. A mudança qualitativa dá-se a partir do momento em que o ministro resolve, com um tom de irritação pela contradição representada pelo comissário, suspender os "nomes em cifra", grifo em negrito, indicando uma alteração na sua atitude. De uma posição dialógica propensa a um convencimento retórico do comissário, o ministro despoja-se de qualquer ambiguidade de linguagem e apresenta sua pergunta de modo literal ao comissário, o qual, por sua vez, responde de maneira contrária ao esperado pelo governo. A partir de então, as relações alteram-se, muito embora ambas as personagens permaneçam atreladas ao aparato estatal: o ministro desvela-se em todo o seu autoritarismo e violência, ordenando o assassinato do comissário, e este mostra-se extremamente solidário para com a mulher do médico, posicionando-se em defesa daquilo que considera seu dever de justiça.

Em As intermitências da morte, a personagem morte surpreende, especialmente, ao enamorar-se pelo músico. E a surpresa advém em razão de sua condição sobrenatural, como algo que não é humano e que, grosso modo, deveria ser incapaz de amar, mas que, contrário senso, sente amor pelo violoncelista. Sua transformação, no entanto, é coerente com o mundo ficcional, sendo construída paulatinamente, em um movimento de recrudescente humanização de sua figura e de sua personalidade. A mudança qualitativa ocorre no momento em que trava relações, possivelmente sexuais, com o homem e, também possivelmente, adormece, deixando de matar no dia seguinte. A morte, enquanto personagem protagonista, 
transita de uma posição de poder e onipotência inabalável para uma condição de vulnerabilidade própria ao ser humano, suscetível, por exemplo, de se emocionar e chorar ao ouvir uma música e, par excellence, de se apaixonar.

Considerando as três personagens apresentadas, podemos sugerir, au passant, uma aproximação das mesmas ao herói mediano de Lukács ${ }^{2}$, para quem:

O caráter intermediário do herói, tão conveniente para o romance, é um princípio formal de composição que pode se exteriorizar na prática literária das mais variadas maneiras [...] Trata-se apenas de encontrar aquela figura central em cujo destino se cruzam os extremos essenciais do mundo representado no romance, em torno da qual, em consequência, é possível construir todo um mundo, na totalidade das suas vivas contradições (LUKÁCS, 2010, p. 179).

Com efeito, ao tomarmos como paradigma a tese lukacsiana, as três personagens protagonistas aqui em análise se apresentam em sua qualidade de homens triviais, medianos, enfim, como o homem do dia-a-dia, do cotidiano, frugal ou prosaico. E, mais do que isso, são capazes de pôr em relação as forças antagônicas dos universos ficcionais representados. A mulher do médico faz a mediação entre a cegueira e a visão, tanto a que se refere à moral, quanto à física, sem mencionar que também é o ponto mediano entre os cegos "bons" e os cegos "malvados" e, em um extrato mais profundo, põe em relação o racional e o irracional, o moral e o imoral, o humano e o inumano, o democrático e o autoritário. E, dessa mediação, ocorrem as sínteses dialéticas, considerando-se a unidade do múltiplo que forma cada situação total do universo romanesco. O comissário de polícia, a sua vez, também é o ente mediador das forças em oposição, no caso o governo e os governados. Igualmente, põe em relação a democracia e o autoritarismo, o moral e o imoral, o humano e o inumano, o legal e o ilegal, construindo, pela relação tensa entre as forças antitéticas, a síntese dialética, segundo a lei da unidade das contradições. A personagem morte, enfim, põe em contato a vida e a morte, o humano e o inumano, o moral e o imoral, o amor e a indiferença brutal, para, também pela unidade das contradições, ensejar o movimento, quer das personagens, quer do mundo ficcional. No entanto, não queremos nos estender nessa linha de argumentação, uma vez que ela demandaria um estudo detalhado e específico da personagem segundo o modelo lukacsiano. No momento, para nosso argumento, importa frisar que a possível associação dos heróis de

\footnotetext{
2 Uma explanação da aderência das protagonistas de José Saramago ao conceito de herói mediano de Lukács pode ser apreendida no trabalho de Conrado (2006).
}

José Saramago ao conceito de Lukács, longe de constituir um óbice, apresenta-se como um fator de confirmação de suas qualidades dialógicas e dialéticas.

As personagens saramaguianas, portanto, caracterizam-se pelo aspecto transformacional, recusando-se a uma tipificação estática ou linear; é pelo contato com a alteridade, pela apreciação de um mesmo fato sob diferentes pontos de vista; pelo diálogo interior conflituoso e outros processos relacionais que se autorrevelam dialogicamente. Não se trata, todavia, de um dialogismo restrito a uma forma de conciliação, mas, sim, da contraposição, do contraponto, da antítese, sugerindo, certamente, um diálogo qualificado, ou seja, dialético. Em José Saramago, temos a representação da vida de homens comuns, no contato com outros homens comuns, em situações de extrema crise, de modo que o diálogo adquire função essencial no desvelamento de uns e de outros, construindo-se uma personagem dotada de vitalidade, complexidade e relevância. As personagens saramaguianas são vivas e dinâmicas, recusando a inércia objetal e passível de manipulação do autor ${ }^{3}$; são relativamente livres e se revelam justamente pelo "esquema básico do diálogo [...] a contraposição do homem ao homem como contraposição do 'eu' ao 'outro' (BAKHTIN, 2010a, p. 293 - grifo do autor). O acabamento artístico dialógico e dialético das personagens, então, funciona de maneira a viabilizar o conteúdo humanista-democrático, por meio de um movimento marcado pelo choque de contradições - de maneira relacional. A personagem, ao mesmo tempo em que simboliza o postulado do conteúdo, informa sobre a posição axiológica enfatizada nas narrativas, contribuindo para a construção extradiegética de um homem humanitário, distante dos nefastos valores ligados à cultura do capital.

\section{Referências}

ARNAUT, Ana Paula. José Saramago: singularidades de uma morte plural. In: Revista de Letras, Universidade de Trás-osMontes e Alto Douro, Portugal, v. 5, n. 2, p. 107-120, 2006.

BAKHTIN, Mikhail M. Problemas da Poética de Dostoiévski. Tradução, notas e prefácio Paulo Bezerra. 5. ed. Rio de Janeiro: Forense Universitária, 2010a.

Para uma filosofia do ato responsável. Tradução Valdemir Miotello e Carlos Alberto Faraco. 4. ed. São Carlos: Pedro e João editores, 2010 b.

\footnotetext{
É interessante citar o entendimento de José Saramago quanto à vida das personagens, pois reforça a ideia de que as mesmas são relativamente livres, independentes e autônomas, dotadas de uma autoconsciência. Sobre a criação das personagens, o autor afirma que é "criador dessas personagens, mas, ao mesmo tempo, criatura delas" (SARAMAGO, 2013, p. 76). Em relação à liberdade das personagens, o escritor sugere que não as controlava, embora inicialmente assim o cresse: "essa gente que eu acreditava ir guiando de acordo com as minhas conveniências de narrador e obedecendo à minha vontade de autor" (SARAMAGO, 2013, p.76).
} 
BÍBLIA SAGRADA. São Paulo: Paulinas, 2005.

CANDIDO, Antonio. A personagem do romance. In: et al. A personagem de ficção. São Paulo: Perspectiva, 2011.

CONRADO, Iris Selene. O ser humano e a sociedade em Saramago: um estudo sociocultural das obras Ensaio sobre a cegueira e Ensaio sobre a lucidez. Dissertação (Mestrado em Letras) - Universidade Estadual de Maringá, Maringá, 2006.

FORSTER, E. M. Aspectos do romance. Tradução Maria Helena Martins. Porto Alegre: Globo, 1969.

HAMON, P. Por um estatuto semiológico da personagem. In: CARVALHAL, Tânia Franco et al. (Org.). Masculino, Feminino, Neutro: ensaios de semiótica narrativa. Tradução Tânia Franco Carvalhal et al. Porto Alegre: Globo, 1976.

LEFEBVRE, Henry. Lógica formal/Lógica dialética. Tradução Carlos Coutinho. Rio de Janeiro: Civilização Brasileira, 1975.

LUKÁCS, G. Marxismo e Teoria da Literatura. Tradução Carlos Coutinho. 2. ed. São Paulo: Expressão Popular, 2010.

SARAMAGO, José. Ensaio sobre a cegueira. São Paulo: Cia das Letras, 1995.
Ensaio sobre a lucidez. São Paulo: Cia das Letras,
2005.

As intermitências da morte. São Paulo: Cia das Letras, UFPA, 2013

SARTRE, Jean-Paul. O existencialismo é um humanismo. Tradução de João Kreuch. 4. ed. Rio de Janeiro: Vozes, 2014.

TOMACHEVSKI, Boris. Temática. In: TODOROV, T. (Org.). Teoria da literatura: textos dos formalistas russos. Tradução Roberto Ferreira. São Paulo: UNESP, 2013.

\section{Autores:}

DEIVIS JHONES GARLET

Universidade Federal de Santa Maria.

Porto Alegre, RS, Brasil.

deivisjh@hotmail.com

ROSANI KETZER UMBACH

Universidade Federal de Santa Maria.

Porto Alegre, RS, Brasil.

rosaniumbach@gmail.com

Recebido: 04/05/2017

Aprovado: 04/05/2017 